Indonesian Journal of Global Health Research

Volume 3 Number 1, February 2021, pp. 101 - 108

e-ISSN 2715-1972; p-ISSN 2714-9749

http://jurnal.globalhealthsciencegroup.com/index.php/IJGHR

\title{
MANAGEMENT OF DISCHARGE PLANNING IMPLEMENTATION ON CHRONIC RENAL FAILURE PATIENTS
}

\author{
Rahayu Winarti*, Dwi Retnaningsih, Priharyanti Wulandari \\ Universitas Widya Husada Semarang, Jln. Subali Raya No. 12 Krapyak Semarang Jawa Tengah, Indonesia \\ 50146 \\ *rahayuwh57@gmail.com
}

\begin{abstract}
Patients with Chronic Renal Failure experience an inability of the body to remove metabolic waste. Hemodialysis and regulation of nutritional intake are efforts to maintain their health condition. The information provided so that patients understand and comply with the therapy is very important to prevent emergency conditions. Therefore, Discharge Planning is very important on patients with Chronic Renal Failure to provide information concerning the sustainable health needs after patients' discharge, implementing evaluation and directing the self-care. This study aimed to determine the management of Discharge Planning implementation for clients with chronic renal failure in the Hemodialysis Room at Ungaran General Hospital. The research design used was a case study with an embedded single case study. Participants in the study were nurses and patients with Chronic Renal Failure who were selected using purposive sampling. The data were collected through semi-structured interviews and discharge planning documentation studies. The number of participants in the study were three nurse executors of hemodialysis and 3 patients who received hemodialysis therapy. Informant consent was submitted for the informants' approval prior to the interview. The data collected from the interviews were analyzed using pattern matching techniques. Based on the research, it shows that the role of nurses in the hemodialysis room is the most important in implementing Discharge Planning as educator executor, and managerial role is carried out by the head of the ward.
\end{abstract}

Keywords: chronic renal failure; discharge planning; role of nurses

\begin{tabular}{|c|c|}
\hline $\begin{array}{c}\text { First Received } \\
22 \text { December } 2020\end{array}$ & $\begin{array}{c}\text { Revised } \\
28 \text { December } 2020\end{array}$ \\
\hline $\begin{array}{c}\text { Final Proof Received } \\
20 \text { February } 2021 \\
\end{array}$ & $\begin{array}{c}\text { Published } \\
\text { 28 February } 2021 \\
\end{array}$ \\
\hline $\begin{array}{l}\text { How to cite (in APA style) } \\
\text { Winarti, R., Retnaningsih, D., \& Wul } \\
\text { on Chronic Renal Failure Patient } \\
\text { https://doi.org/10.37287/ijghr.v3i1.35 }\end{array}$ & $\begin{array}{l}\text { P. (2021). Management of Discharge Planning Implementation } \\
\text { nesian Journal of Global Health Research, 3(1), 101-108. }\end{array}$ \\
\hline
\end{tabular}

\section{INTRODUCTION}

Chronic Renal Failure (CRF) is a progressive and irreversible renal function disorder, where the body is unable to maintain metabolism and fails to maintain fluid and electrolyte balance which results in increased urea (Desfrimadona, 2016). The Glomerulo Filtration Rate (GFR) value shows how much kidney function is owned by the patient as well as the basis for determining therapy by the doctor. The more severe chronic renal failure experienced, the lower the GFR value (Krueger et al., 2005).

According to the World Health Organization (WHO), chronic renal failure contributes to the world's disease burden with a death rate of 850,000 people per year (Pongsibidang, 2016). The results of the 2010 Global Burden of Disease study showed that chronic renal failure was the $27^{\text {th }}$ leading cause of death in the world in 1990 and increased to $18^{\text {th }}$ place in 2010 (Indonesian Ministry of Health, 2018). Based on the Indonesian Renal Registry (IRR) of the Pernefri data center, the number of patients in 2016 who underwent dialysis was 52,835 people, with the number of new patients as many as 25,446 people. 
The results of Basic Health Research in 2013 and 2018 showed that the prevalence of chronic renal failure in Indonesia $\geq 15$ years based on a doctor's diagnosis in 2013 was $0.2 \%$ and an increase in 2018 was 0.38 . The highest prevalence of chronic renal failure is in Central Sulawesi Province $(0.5 \%)$, while for Central Java Province it is $0.3 \%$, which means it is above the national prevalence (0.2\%) (Ministry of Health of the Republic of Indonesia, 2018). Based on the Preliminary Study at Ungaran Hospital in 2019, there were 70 (Seventy) renal failure patients with hemodialysis.

When chronic renal failure has reached its end stage and the kidneys are no longer functioning, a way is needed to remove toxic substances from the body with kidney replacement therapy, namely dialysis (hemodialysis), continuous ambulatory peritoneal dialysis (CAPD), and kidney transplantation. The most widely replacement therapy used in Indonesia is hemodialysis. Hemodialysis is a therapy used to replace damaged kidney function by using a device called a hemodialysis machine, which will cause diffusion, osmosis and ultrafiltration processes to remove the remaining metabolism in the body.

Patients must take medication for comorbidities, receive hemodialysis two to three times a week, and regulate food intake (protein, fat, carbohydrates, sodium and minerals) (Azis et al, 2008). However, patients sometimes do not understand and comply with the therapy program. Discharge planning is a mechanism for providing continuous nursing care, providing information about ongoing health needs after the patient is discharged, carrying out evaluation and directing for self-care (Swanburg, 2000). (Krueger et al., 2005) stated that one of the important factors in influencing the level of compliance is the interaction or relationship between the staffs being analyzed and the patients. This is in line with previous research (Ningsih et al., 2012) that there was a positive relationship between the level of compliance to fluid restriction in $\mathrm{CRF}$ patients undergoing hemodialysis after receiving health education from nurses about fluid restriction.

In addition, Wahyu Rianti showed that there was an effect of knowledge on diet noncompliance in chronic renal failure patients who were undergoing hemodialysis therapy (Wahyu, 2017). Non-compliance in running the therapy program can lead to emergency conditions and an increase in re-treatment rates (Bauer, Fitzgerald, Haesler \& Manfrin 2009). Azimatunnisa's 2011 study showed a significant relationship between discharge planning and the level of patient readiness in facing discharge (Azzimatunnisa, 2011). Therefore, discharge planning is very important for chronic renal failure patients. Through discharge planning, it is expected that patients will have a good understanding of therapy programs, independent care that is carried out after discharging from the hospital (Maslakha \& Heris Santy, 2018) and high sodium and potassium food ingredients.

Discharge Planning is a discharge plan written on a nurse's note sheet which is the goal of patient care planning, ultimately aims to empower clients to make decisions and strive to maximize life potential independently, and to empower patients through support and existing resources in the family and community. Discharge Planning as a part of nursing care will be optimally implemented if it is supported by the implementation of a good management function. Nursing activities related to management functions include planning, organizing, employment, directing and controlling (Sulistyawati, 2016). Based on research conducted by Hardivianty (2017), it was known that there are still hospitals that have not been maximal in carrying out discharge planning, including: human resources who do not understand the importance of discharge planning, the unavailability of Standard Operating Procedures (SOP) and appropriate guidelines for the discharge plan, as well as the existence of obstacles 
originating from personnel factors, namely service providers and recipients (Hardivianty, 2017).

If discharge planning fails to be provided, it will be at risk of the disease severity, life threats, and physical dysfunction (Nursalam, 2009). The implementation of Discharge Planning requires the role of health workers to provide sufficient information to patients regarding the therapy program. Through proper discharge planning, it is expected that the patient's quality of life can be optimal. The purpose of this study was to determine the management of discharge planning in patients with chronic renal failure in the Hemodialysis Room of Ungaran General Hospital.

\section{METHOD}

The research design used was descriptive qualitative with a case study approach with the embeded single case study method. Informants selected in this research, are patients and nurses using purposive sampling method. In the study, there were three units of analysis, namely nurses, patients and the head of the hemodialysis ward. In the first unit of analysis, the required participant criteria were nurses who work to treat chronic renal failure patients in the hemodialysis ward and have at least one year of work experience, since it means that the nurses has adapted to the patient and already understands the implementation of Discharge Planning. In the second unit of analysis, the required participant criteria were chronic renal failure patients who received routine hemodialysis therapy twice a week, both new and old patients, while the third analysis was the head of the hemodialysis ward who treated chronic renal failure patients who played a role in triangulating the data. This research was conducted in Hemodialysis Ward of Ungaran General Hospital in February 2020. Data were collected using semi-structured interviews and discharge planning documentation studies. The data analysis technique used in this study was pattern matching analysis, which is comparing the initial estimation before data collection with findings/facts in the field (Yin Robert, K, 2014). The validity of the data was checked using the triangulation technique.

\section{RESULTS}

The implementation of this research resulted in 3 themes, namely (1) the role of the nurse as an educator in the implementation and benefits of discharge planning for patients, (2) the nurse as the executor of discharge planning, and (3) the head of the ward as the manager in carrying out discharge planning on patients with chronic renal failure. In the implementation of this study, interviews were conducted with 3 nurses according to the inclusion criteria and the Head of the hemodialysis room at Ungaran General Hospital and 3 patients with chronic renal failure who received hemodialysis therapy.

The important role of nurses in the implementation of discharge planning on patients with chronic renal failure (CRF) is the role of educators.

The following are participants' statements about the importance of the role of educators:

"I used to experience shortness of breath and sometimes felt weak. My body felt hot so I often drank a lot. I also like to eat fruits that contain lots of water and rarely eat vegetables, but now the treatment has often been explained so that I understand. Now I limit drinking water and try not to drink cold water, eat protein and vegetable foods, and always take medicine regularly." Participant 1

"I used to experience nausea, vomiting and was very weak, until now I still have nausea and vomiting. In the past, when I experienced nausea, vomiting and weakness, I did not want to eat at all, but then the nurse often explained that I need to force myself to eat even a little but 
often and limiting my protein intake, especially from vegetables such as tofu and tempeh and taking medication regularly." Participant 2

The executive nurse plays the role of executing discharge planning and the head of the ward plays the managerial role.

The following are participants' statements regarding the theme:

"First, we will examine whether the patient and his family already understand the disease suffered and how the treatment at home will be. If they are not understand yet, we need to explain the self-care while at home. The most important thing to do for a patient at home is how to maintain his diet, take medication regularly, and comply with hemodialysis therapy in the hospital." Participant 1

"Conducting a prior assessment of the information needed by the patient, involving the family in home care, apart from motivating to keep up with the condition of the disease, we also provide information for self-care at home, about eating, diet, taking medication regularly and coming to hospital for regular dialysis." Participant 2

Lifestyle changes experienced by chronic renal failure patients including diet, fluid regulation, medication, and activity restrictions.

The following is the participants' statement about the theme:

"I sold food in the market before, but due to diagnosed with renal failure, now I end up selling food at home. So to keep my health, I stay at home. What must be maintained is WFS: Water, fruit, and salt. We should not be tired in doing activities as well and receive regular HD. " Participant 3

\section{The cause of inadequate implementation of discharge planning}

The following are participants' statement regarding the inadequate implementation of discharge planning:

"Probably from the people, whether it is from the nurses or patients. The education sometimes is low, so it is hard to understand and we have to repeat things, and sometimes the nurses are also busy." Participant 1

"In my opinion, this has not been implemented well, because there has never been any socialization or training on discharge planning. Sometimes the documentation is incomplete."

\section{Participant 2}

\section{DISCUSSION}

The important role of nurses in the implementation of discharge planning on patients with chronic renal failure (CRF) is the role of educators.

Patients can get information and knowledge so that they can take care for themselves at home or after returning from the hospital because of the important role of nurses as educators. The results showed that patients were able to perform diet as recommended and were able to handle side effects of dialysis independently at home because of the role of nurses as educators. This is in line with research conducted by Ana Maria in 2014 stating that discharge planning can help patients' independence and readiness in performing self-care at home (Maria Ana, 2014). Patients with Chronic Renal Failure must undergo hemodialysis therapy and maintain their diet continuously so that their health condition can be maintained properly therefore the role of nurses as educators is very important to provide information and knowledge. A good understanding of the goals must be considered by the patient, so that the patient can be consistent and comply with the treatment given to him. 
This is in line with the research conducted by Winami $\mathrm{T}$ in 2018 regarding the role of educators and the implementation of discharge planning, concluding that there is a relationship between the role and implementation of discharge planning with the level of patient compliance for control, in this case if the role of the educator is good, then the patient will obey the control according to schedule (Winarni et al., 2018).

\section{The executive nurse plays the role as executor of discharge planning and the Head of the Ward plays a ministerial role.}

In addition to playing the role of educators, nurses also play a role as discharge planning or nursing care providers. The nurse assesses the patient's condition, ensures and provides information to the patient about laboratory results, for example: $\mathrm{Hb}$ and creatinine are within normal limits, and do not experience shortness of breath. Then, the nurse provides discharge planning according to patient needs and evaluates the discharge planning that has been implemented. This is in line with Cynthia Hardivianty's research in 2017 who stated that several discharge planning processes that must be carried out are an assessment of health service needs, an assessment of health education needs for patients and families, and an assessment of environmental factors that can interfere with self-care (Hardivianty, 2017).

Research conducted by Safrina and Putra in 2016 on the perception of executive nurses on the importance of discharge planning concluded that nurses perceive that sustainable care at home in discharge planning is important to be provided (Safrina \& Putra, 2016). The implementation of the management function states that it is needed in the implementation of discharge planning and the higher the perception of the nurse in charge of the management function, the higher the implementation of discharge planning (Sulistyawati, 2016).

\section{Lifestyle changes experienced by chronic renal failure patients including diet, fluid regulation, medication, and activity restrictions.}

Chronic renal failure causes patients to experience lifestyle changes such as diet, fluid regulation, medication, hemodialysis, and activity restriction. Based on the research results, it was known that patients with Chronic Renal Failure are forced to reduce their workload to maintain their health condition, besides that patients with Chronic Renal Failure are also required to comply and understand the types of foods and fruits that can and should not be consumed, schedule for hemodialysis, and the amount of fluids that are allowed to drink. Patients with Chronic Renal Failure who are also diagnosed with other diseases such as Diabetes Mellitus stated that it was very difficult to restrict fluids, because they continued to feel thirsty so that they sometimes experience swelling and shortness of breath.

The majority of patients who received information about disease, activity management, medication, nutrition, and complications did not experience feelings of worry which led to visits to health facilities (Azzimatunnisa, 2011). The results showed that patients who had been diagnosed with CRF for a long time had better understanding of what to do to maintain their health, such as not consuming fruit containing potassium, foods that can increase creatinine, and how to deal with the side effects of dialysis. This is because patients who have been diagnosed with CRF for a long time have more experience and knowledge. To provide accurate information about the diet to CRF patients, the nurse collaborates with a nutritionist.

Heni, et al. In 2017 regarding the implementation of discharge planning in hospitals stated that an explanation of nutrition can help patients to improve their health status (Marliany, Permana, \& Permatasari, 2017). In addition, Lilik and Wesiana in 2015 regarding the level of 
compliance of CKD patients stated that understanding diabetes food will help improve nutrition and prevent complications such as hyperglycemia (Maslakha \& Heris Santy, 2018)

\section{The cause of the inadequate implementation of discharge planning}

Based on the research results, it is known that the obstacle that causes the implementation of discharge planning is not optimal is the personnel factor, namely service providers and recipients. In this case, it is considered to be an internal and external obstacles. Internal obstacles come from nurses, including nurses' workload and motivation. The high workload causes nurses to do various jobs at once, so that in discharge planning nurses tend to only carry out important stages. Workload is one of the factors causing the less optimal role of nurses as educators in providing a sense of security to patients (Agustin, 2017). The nurses' low motivation in discharge planning causes the discharge planning documentation is not maximal.

This is in line with the research conducted by Nazvia Natasia, et al. In 2014 regarding the Relationship between Motivation and Supervision Factors and Nurse Performance in Discharge Planning Documentation, stating that nurses' motivation is related to nurses' performance in documenting discharge planning. Nurses who have high motivation will complete discharge planning documentation (Natasia et al., 2014). As discharge planning executors, nurses must have a good understanding of discharge planning itself. Based on the results of the study, it was found that there had never been any detailed socialization or training related to discharge planning by nurses, so the discharge planning was not yet maximized.

The ability of nurse nurses after receiving planning training is better than before getting training (Febrianti et al., 2012). The external barrier that comes from the patient is that it is difficult for the patient to understand the information. Factors that make it difficult for patients to understand information are the length of treatment and the level of education of the patient. Patients treated in third grade wards with low education are more difficult to understand information than highly educated patients so that it requires repetition of education by nurses. Higher education indicates broader knowledge and allows patients to be able to control themselves in overcoming the problems at hand, and easily understand what is being taught by health workers (Goleman, Daniel; boyatzis, Richard; Mckee, 2019) The understanding of someone on disease significantly affects their ability to manage complex medical and emotional problems (Robert L.Karolich, 2010). Therefore, the nurse as the executor of discharge planning is responsible for carrying out the role of the educator as best as possible, so that patients can have a good understanding even though they have low education. Seeing the importance of implementing discharge planning for patients, the existing obstacles need to be overcome and discharge planning implementation needs to be optimized so that the patient's health status can increase.

\section{CONCLUSION}

In the management of discharge planning for patients with chronic renal failure at the Ungaran Regional General Hospital, it is known that the very important role of nurses as an educator is the main role in treating the patients, so that it is important for the nurses to provide health education about the patients' independence after discharging from hospital and a managerial role by the head of the room. The workload and lack of motivation of nurses are internal obstacles for the less than optimal discharge planning, while external obstacles come from patients who tend to find it difficult to receive information. Education given to patients 
has not been implemented programmatically so that it fits the patient's needs and can increase patient satisfaction.

\section{REFERENCES}

Aap Apipudin1, Heni Marliany 2, Arif Nandang, 3. (2017). Jurnal Ilmiah Kesehatan Keperawatan, Volume13, No. 1February 2017. Penatalaksanaan Persiapan Pasien Preoperatif Di Rumah Sakit Umum Daerah Kabupaten Ciamis, 13(1), 2-7.

Agustin, R. (2017). Optimalisasi Pelaksanaan Discharge Planning Melalui Pengembangan Model Discharge Planning Terintegrasi Pelayanan Keperawatan. Journal Keperawatan Muhamadiyah FIK UMSURABAYA, 2(1), 92-101. http://repository.umsurabaya.ac.id/2972/1/Jurnal_DP_Ratna_(1).pdf

Azzimatunnisa. (2011). Hubungan Discharge Planning Dengan Tingkat Kesiapan Klien Dalam Di Rs Pku Muhammadiyah.

Desfrimadona, D. (2016). KUALITAS HIDUP PASIEN GAGAL GINJAL KRONIK DENGAN HEMODIALISA DI RSUP DR M DJAMIL PADANG TAHUN 2016. http://scholar.unand.ac.id/id/eprint/5350

Febrianti, L., Yani, A., Hamid, S., Priscilla, V., Kep, M., \& Mat, S. (2012). Pengaruh Pelatihan Terhadap Kemampuan Perawat Pelaksana Melakukan Perencanaan Pulang Pasien Diabetes Mellitus di Rumah Sakit Dr. M. Djamil ... https://www.academia.edu/download/42834142/Artikel.pdf

goleman, daniel; boyatzis, Richard; Mckee, A. (2019). Korelasi Self Efficacy dan Social Support dengan Kepatuhan Menjalani Hemodialisis pada Pasien Cronic Kidney Disease (CKD) DI RSUD Dr. H. SOEWONDO KENDAL Eny. Journal of Chemical Information and Modeling, 53(9), 1689-1699.

Hardivianty, C. (2017). Evaluasi Pelaksanaan Discharge Planning di Rumah Sakit PKU Muhammadiyah Gamping Yogyakarta. Proceeding Health Architecture, 1(1), 21-34. http://mmr.umy.ac.id/wp-content/uploads/2017/05/Cynthia-Hardivianty_Page-2134.pdf

Hollweck, T. (2016). Robert K. Yin. (2014). Case Study Research Design and Methods (5th ed.). Thousand Oaks, CA: Sage. 282 pages. The Canadian Journal of Program Evaluation, 1(2014), 108-110. https://doi.org/10.3138/cjpe.30.1.108

Kementerian Kesehatan RI. (2018). Laporan Riskesdas 2018. Laporan Nasional RIskesdas 2018, 53(9), 181-222. http://www.yankes.kemkes.go.id/assets/downloads/PMK No. 57 Tahun 2013 tentang PTRM.pdf

Krueger, K. P., Berger, B. A., \& Felkey, B. (2005). Medication adherence and persistence: A comprehensive review. Advances in Therapy, 22(4), 313-356. https://doi.org/10.1007/BF02850081

Maria Ana, S. (2014). Hubungan Persepsi Perawat tentang Manfaat Discharge Planning Dengan Pelaksanaan Discharge Planning Di Ruang Rawat Inap Rumah Sakit PKU Muhammadiyah Yogyakarta. 8-9.

Maslakha, L., \& Heris Santy, W. (2018). Analisa Pemahaman Discharge Planning dengan Tingkat Kepatuhan Pasien Gagal Ginjal Kronik (GGK) Dalam Menjalani Terapi 
Hemodialisis Di Rumah Sakit Islam Jemursari Surabaya. In Journal of Health Sciences (Vol. 8, Issue 1). https://doi.org/10.33086/jhs.v8i1.217

Natasia, N., Andarini, S., \& Koeswo, M. (2014). Hubungan antara faktor motivasi dan supervisi dengan kinerja perawat dalam pendokumentasian discharge planning di RSUD Gambiran kota Kediri. Jurnal Aplikasi Manajemen, 12(66), 723-730.

Ningsih, E. S. P., Rachmadi, A., \& Hammad, H. (2012). Tingkat kepatuhan pasien gagal ginjal kronik dalam pembatasan cairan pada terapi hemodialisa (the compliance chronic renal failure patient on restrictions liquids in hemodialysis therapy). Jurnal Ners, 7(1), 24-30.

Purnamasari, L. D., \& Ropyanto, C. B. (2012). Evaluasi Pelaksanaan Perencanaan Pulang. Diponegoro Journal of Nursing, 1(1), 213-218.

Robert L.Karolich. (2010). Meaning, Comprehension, and Manageability of End-Stage Renal Disease in Older Adults Living with Long-Term Hemodialysis. Social Work in Health Care, 49(1), 19-37. https://doi.org/https://doi.org/10.1080/00981380902958601

Safrina, N., \& Putra, A. (2016). Persepsi Perawat Pelaksana Terhadap Pentingnya Discharge Planning Di RSUDZA Banda Aceh Rsudza Banda Aceh. Jurnal Iilmiah Mahasiswa Fakultas Keperawatan, 1(1), 1-9. http://jim.unsyiah.ac.id/FKep/article/view/1597/1879

Sulistyawati, W. (2016). Implementasi fungsi manajemen dalam pelaksanaan discharge planning. Jurnal Ilmiah Keperawatan, 10(1), 890-896.

Wahyu, R. (2017). Faktor-Faktor Yang Mempengaruhi Ketidakpatuhan Diit Pasien Gagal Ginjal Kronik Yang Menjalani Hemodialisa Di Ruang Hemodialisa Rsud Dr.Soedirman Kebumen. Skripsi Sekolah Tinggi Ilmu Kesehatan Muhammadiyah, 1-57.

Winarni, T., Sujana, T., \& Gasong, D. N. (2018). Manajemen Discharge Planning pada Pasien Gagal Ginjal. Junal Ilmu Keperawatan Dan Kebidanan, 9(2), 65-72. 